\title{
0 ESPELHO INVERTIDO IMPRESSÕES PERNAMBUCANAS SOBRE 0 CARNAVAL DAS ESCOLAS DE SAMBA DO RIO DE JANEIRO
}

Hugo Menezes Neto (UFPA)

Neste artigo sistematizo as impressões produzidas pelas lideranças das escolas de samba do Recife acerca das cariocas. O intuito é explorar o imaginário social pernambucano em sua relação com o "modelo ideal" de carnaval, pensando que a elaboração de imagens sobre o outro também evidencia a construção da autoimagem.

ESCOLAS DE SAMBA, CARNAVAL, REPRESENTAÇÕES SOCIAIS.

MENEZES NETO, Hugo. O espelho invertido: impressões pernambucanas sobre o carnaval das escolas de samba do Rio de Janeiro. Textos escoIhidos de cultura e arte populares, Rio de Janeiro, v.11, n.2, p. 7-28, nov. 2014. 


\section{THE INVERTED MIRROR}

IMPRESSIONS FROM THE STATE OF PERNAMBUCO

OF THE SAMBA SCHOOLS CARNIVAL OF RIO DE JANEIRO

Hugo Menezes Neto (UFPA)

In this article I systematize the impressions made by the leaders of samba schools of Recife about the samba schools of Rio de Janeiro. The aim is to explore the social imaginary of these groups of Pernambuco in its relation to the "ideal model" of carnival, assuming that the elaboration of images about the other also denounces the construction of a self-image.

SAMBA SCHOOL, SOCIAL REPRESENTATIONS, CARNIVAL.

MENEZES NETO, Hugo. O espelho invertido: impressões pernambucanas sobre o carnaval das escolas de samba do Rio de Janeiro. Textos escolhidos de cultura e arte populares, Rio de Janeiro, v.11, n.2, p. 7-28, nov. 2014. 
Uma grande expectativa é gerada até o carnaval pelas centenas de agremiações pernambucanas, entre elas as escolas de samba. Estas últimas, entretanto, apresentam dupla expectativa acerca da festa, pois se localizam entre dois carnavais: o do Recife e o do Rio de Janeiro. O primeiro é o de ordem da realidade, da prática artística e política, a passarela pela qual efetivamente desfilam e renovam ciclicamente o trabalho, o amor e o orgulho. O segundo é acompanhado a distância, idealizado, sonhado, e, em certa medida, produto da imaginação e de impressões elaboradas e constantemente (re)alimentadas por informações, tanto quanto por versões e boatos, emanadas do universo do desfile carioca.

Ao pensar sobre a própria experiência (HALL, 2003), ${ }^{1}$ os membros das escolas pernambucanas extrapolam o carnaval do Recife, comparam-se com o "modelo ideal", imaginam como deve ser o "processo ritual do desfile carioca" (CAVALCANTI, 2006). Conectam-se com o outro referencial a partir de imagens construídas, "representações irrealistas" (BECKER, 2009)² a incidir na vida e, inadvertidamente, no processo de produção da autoimagem. Para os brincantes de samba pernambucanos, no entanto, esse outro tão igual é completamente diferente, um espelho invertido.

A produção de impressões acerca das escolas de samba do Rio de Janeiro é um exercício de imaginação, resulta da manipulação de dados concretos e de especulações disseminadas virtualmente; das memórias e narrativas de pernambucanos que estabeleceram algum contato com as escolas do Rio de Janeiro; dos apontamentos pessoais a respeito do desfile carioca e de sua dinâmica de produção. Esses conteúdos circulam e são partilhados, ampliados, consolidados e ressignificados constantemente; em certa medida, tornam-se coletivos, evidenciando o potencial de "sociação" da festa carnavalesca (PEREZ, 2011). ${ }^{3}$

Ressalto, de antemão, que as impressões registradas nas falas pelos pernambucanos, mediadas pela distância, evidentemente, generalizam a experiência das escolas do Rio de Janeiro, idealizam o trabalho e as relações do Grupo Especial e estendem essas apreensões para a totalidade das agremiações cariocas. Os termos, "Lá", "eles", "no Rio" e suas variantes indicam sentidos englobantes e o desconhecimento da heterogeneidade, até mesmo dentro do próprio Grupo Especial do desfile.

Na intenção de trabalhar com o imaginário social (souzA, 2009) ${ }^{4}$ das escolas de samba do carnaval do Recife, iluminar compartilhamentos e certos consensos, neste artigo, parte de minha tese de doutorado, ${ }^{5}$ sistematizo suas impressões no que chamo de três grandes imagens recorrentes, produzidas a partir da pergunta "como é o carnaval das escolas de samba do Rio de Janeiro?". ${ }^{6}$ Assim, destaco as recorrências, conteúdos repetidos por mais de um interlocutor, que 
parecem mobilizar, "expressar sentimentos", "operar ligações" (PEREZ, 2011) entre as escolas de Pernambuco e do Rio de Janeiro; são elas: a imagem da "fonte de inspiração"; a do profissionalismo e organização empresarial do processo de produção, que chamo de "empresas de samba"; e a "imagem da ostentação".

\section{“FONTE DE INSPIRAÇÃO"}

Eu assisto às escolas de samba do Rio no domingo; a gente fica trabalhando aqui e fica assistindo. Aqui inspirar é livre, mas fazer, a gente só faz o possível. Acho importantíssimo porque a gente aprende muita coisa, deveria ser obrigatório porque lá é a fonte de inspiração para todos nós. Às vezes a gente (recifenses e cariocas) está com o mesmo tema, só que a diferença é muito grande, aí você vê que o negócio é dinheiro. Vejo eles e parece um sonho. Já teve vezes que a gente criou coisa na alegoria de um dia para o outro porque viu no desfile, coisa possível, claro, porque às vezes eles fazem o impossível (CORREIA, Samarina).

As escolas do Rio de Janeiro são vistas pelos brincantes de samba pernambucanos como "fonte de inspiração" para seus trabalhos. Ao mesmo tempo, há o reconhecimento da dificuldade em concretizar essa inspiração devido às limitações financeiras, configurando-se uma espécie de admiração platônica. O desfile carioca, portanto, desperta o desejo de ser igual e a resignação no ato de fazer, porque, como declarou Correia, da Escola de Samba Samarina, "às vezes eles fazem o impossível".

Os diretores e componentes entrevistados informaram acompanhar os carnavais do Rio de Janeiro, assistir ao desfile do Grupo Especial, opinar sobre quem deveria ganhar ou perder, embora o Concurso das Agremiações do Carnaval do Recife ocorra na segunda-feira, dia do evento da Marquês de Sapucaí. O domingo de carnaval do sambódromo carioca, então, é a noite esperada e prestigiada pelos que conseguem, às vésperas de seu próprio desfile, assistir à transmissão televisiva. Às escolas da segunda-feira eles assistem com atraso, mas muitos são grandes colecionadores de DVDs dos desfiles, sabem a respeito dos carnavais passados, enredos, vitórias, "injustiças" e compartilham com os sambistas do Rio de Janeiro a "memória carnavalesca" (CAVALCANTI, 2006) relacionada à festa carioca. Compartilham, entre outros aspectos, a admiração e o respeito por nomes do mundo do samba, como Jamelão e Neguinho da Beija-Flor, e outros personagens emblemáticos, como a porta-bandeira Selminha Sorriso; por escolas e baterias específicas, como Mangueira, Beija-Flor, Mocidade, União da Ilha (as mais citadas). ${ }^{7}$ 


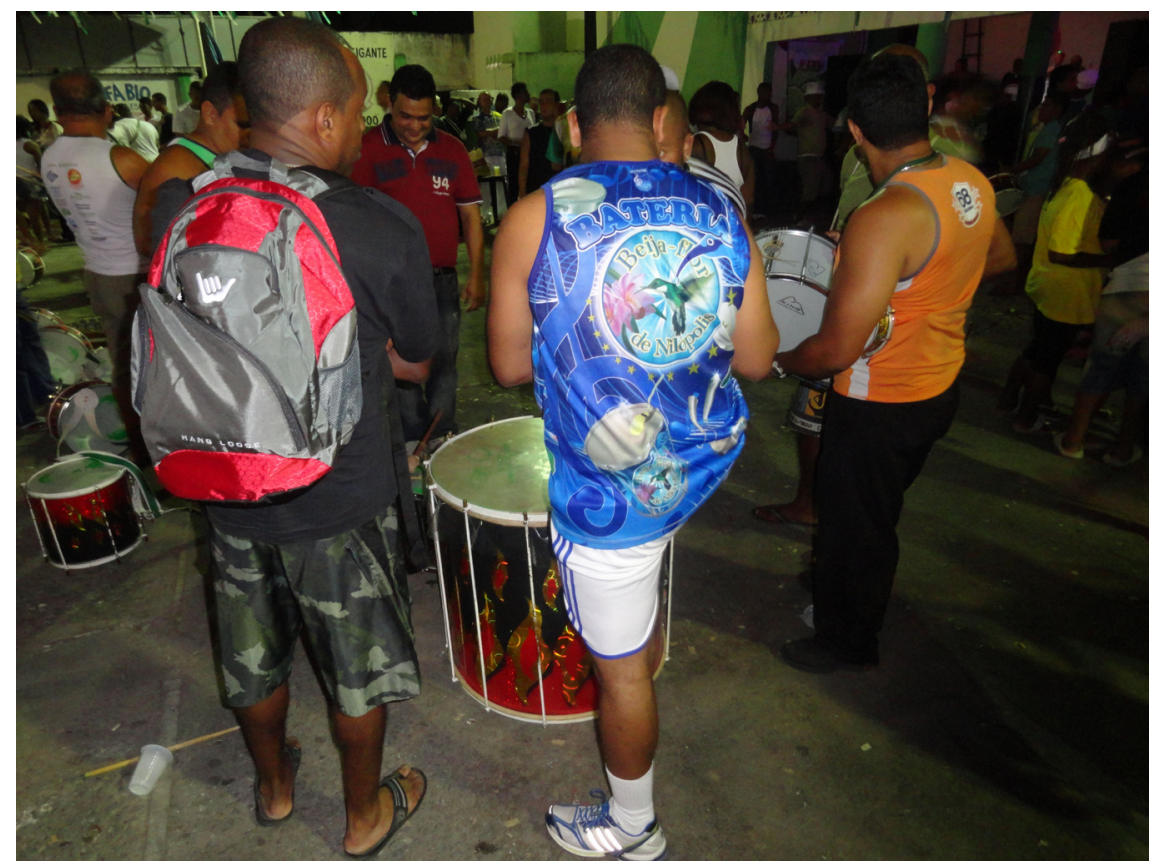

Figura 1: Ensaio da Bateria da Escola Gigante do Samba (Recife), ritmista com camisa da Beija-Flor (Rio de Janeiro) Foto: Hugo Menezes

Senti muito a perda de Jamelão, eu acompanhava o trabalho dele daqui, e para mim foi um baque, como se tivesse perdido um pai. Depois da Mangueira e outra que admiro muito é a Beija-Flor, por causa de Neguinho, ainda sento ao lado dele, tenho fé. Ele faz muito bem o trabalho dele, o samba, a voz. Poxa, ele é tudo! (CARLos ALBERTO, Unidos da Mangueira).

Algumas lideranças, aliás, solicitam aos componentes com funções técnicas e/ou específicas, como passistas e ritmistas, que assistam às escolas, que ouçam os sambas do Rio de Janeiro, como parte da preparação e de qualificação para o carnaval.

Eu costumo escutar os sambas do Rio de Janeiro, e eu mando meus batuqueiros ouvirem, gravo uns piratas e distribuo. Para mim, existe muita diferença, entre nós e eles, e quero chegar mais perto possível deles. A bateria que eu mais gosto no Rio de Janeiro é a Mangueira porque é só uma pancada, é a única bateria diferenciada no Rio de Janeiro. Agora as baterias também me inspiram é a Beija-Flor e a União da Ilha do Governador. Elas conseguem fazer mais trabalhos bonitos no samba, cadenciado, nunca foge do que 


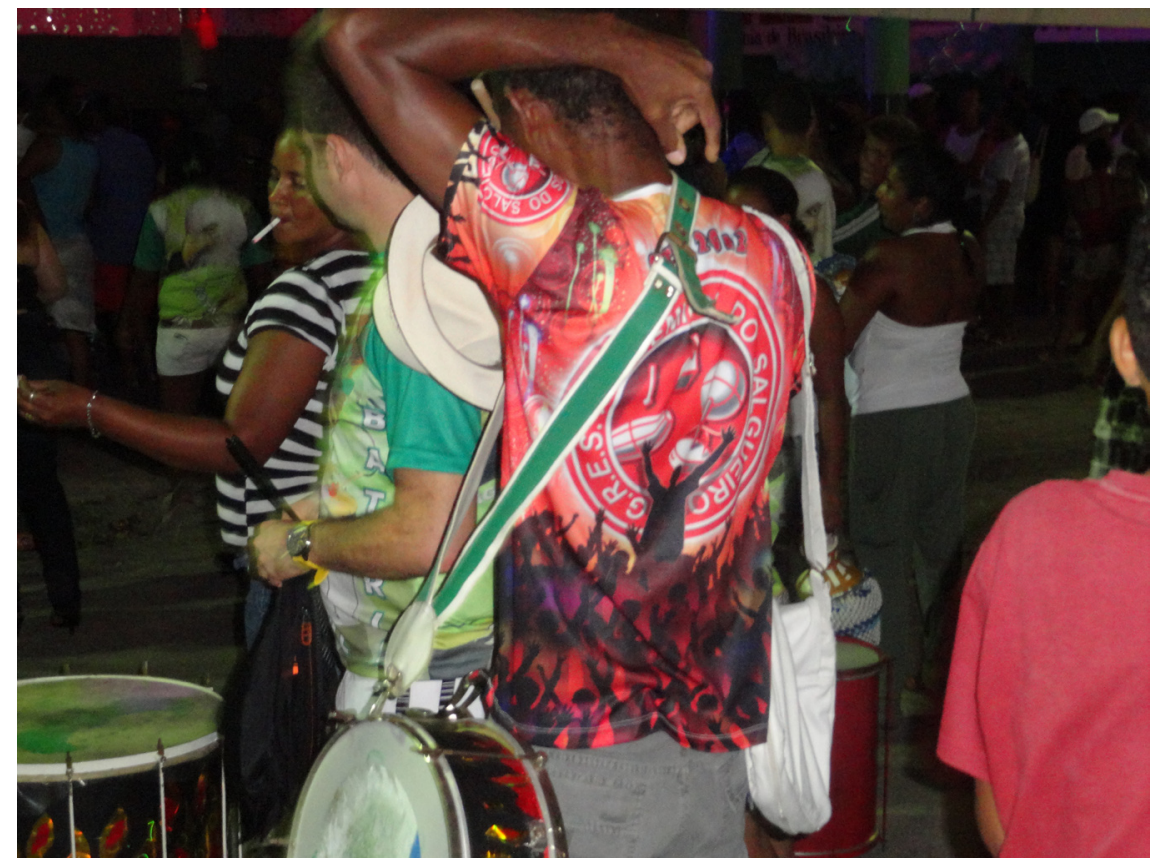

Figura 2: Ensaio da Bateria da Escola Gigante do Samba (Recife), ritmista com camisa da Salgueiro (Rio de Janeiro) Foto: Hugo Menezes

está fazendo, eu me espelho nessas três (FERNANDo, Unidos de São Carlos).

Eu assisto às escolas do Rio, com certeza, porque servem como uma reciclagem pra gente, de aprendizagem, de inspiração. Até as sambistas, eu mando elas assistirem, para elas pegarem o gingado dos passos. Eu mando minha porta-bandeira ver Selminha Sorriso, ela é um escândalo, um arraso! Tem que aprender com a melhor (MARIZE, Gigante do Samba).

Como ocorrência sintomática ou ilustrativa dessa admiração, chama atenção, nos ensaios da bateria da Gigante do Samba, o uso habitual de camisas das escolas do Grupo Especial do Rio de Janeiro, por parte dos seus ritmistas; as mais vistas são Beija-Flor, Salgueiro, Unidos da Tijuca Portela, Vila Isabel e Mangueira (as figuras 1, 2 e 3 atestam esse uso). Cores e símbolos do carnaval carioca misturam-se ao verde e branco da agremiação; no entanto, não encontrei nesses eventos ritmistas vestindo camisas de suas "coirmãs" pernambucanas.

Assistir ao desfile carioca e admirá-lo revelam a conexão da parte com o todo, a partilha de um mesmo universo simbólico. Um movimento que, além do 


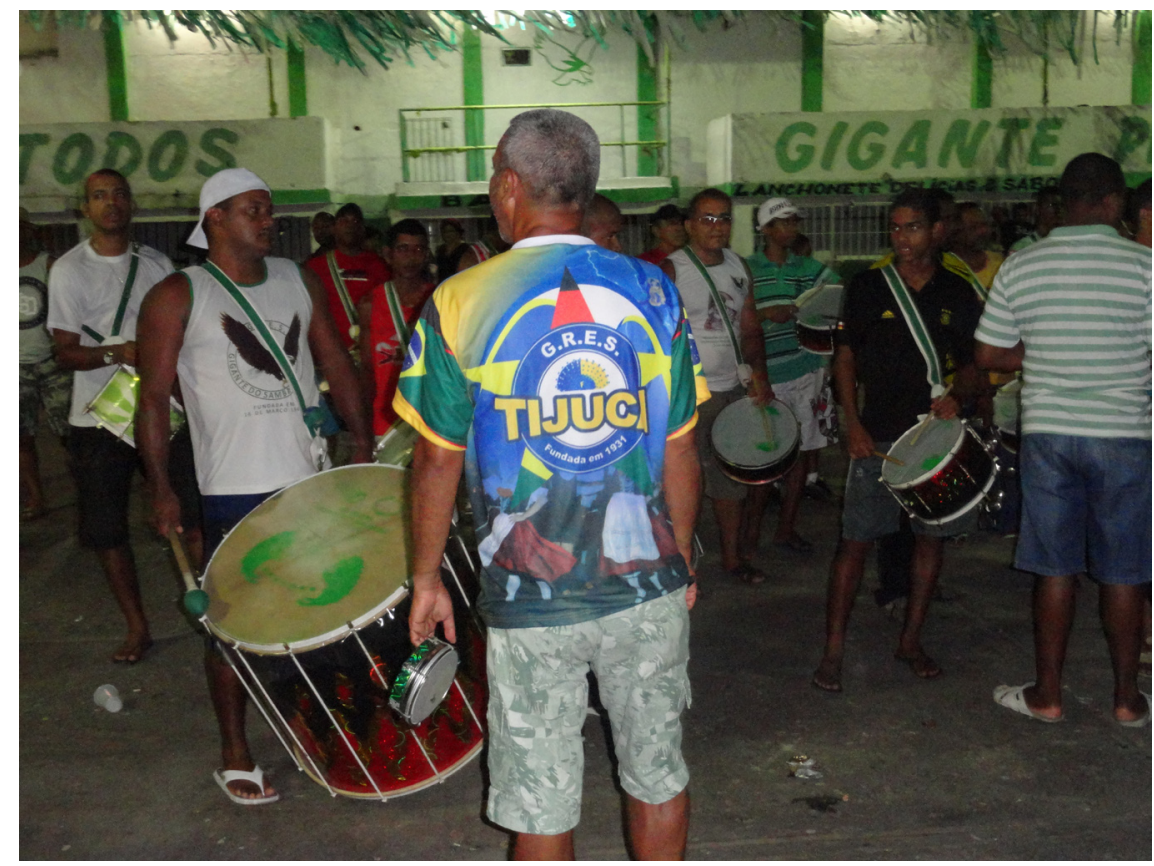

Figura 3: Ensaio da Bateria da Escola Gigante do Samba (Recife), ritmista com camisa da Unidos da Tijuca (Rio de Janeiro) Foto: Hugo Menezes

deleite, é aprendizado e vinculação ao "repertório de significados" (HALL, 2003) das escolas de samba. ${ }^{8}$

Alguns carnavalescos, como Hilário Silva, da Gigante do Samba, viajam todos os anos para o Rio de Janeiro a fim de participar do desfile das campeãs, momento mais oportuno por ser posterior ao Concurso das Agremiações do Carnaval do Recife. ${ }^{9}$ Não vai apenas para se divertir; encara a viagem como aperfeiçoamento; busca a fonte de inspiração e volta com novas ideias.

Todo ano eu vou para o desfile das campeãs. Mando fazer minha roupa e vou desfilar na Beija-Flor. Eu assisto à Gigante na avenida e viajo na quarta-feira de cinzas, a passagem já tá comprada. Eu me inspiro muito, quando eu estou fazendo as fantasias aqui, eu fico me lembrando do que vi lá. (...) É inspiração mesmo: você vê um trabalho e cria o seu em cima dele, mas, com seu material diferenciado. Essa roupa mesmo [ele mostra] foi copiada de uma da Beija-Flor, mas no lugar desses babados, era pluma, e o meio era todo bordado de lantejoula, muito luxo. Como a Gigante não pode luxar muito, mudei... mas tá bonito (HILÁRIO, carnavalesco da Gigante do Samba). 
Como explica o carnavalesco da Gigante do Samba, as restrições financeiras e de material, entretanto, exigem adaptação e criatividade. Logo, a inspiração estética não se traduz na absoluta cópia; trata-se de outro trabalho, embora com base na matriz estética carioca. Insisti com meu interlocutor para qualificarmos melhor a ideia de cópia. Ele, então, elaborou a "teoria da cópia chinesa": todos nós nos copiamos, e os produtos chineses servem de exemplo de um mundo de cópias. Segundo Hilário, as ruas do Recife estão invadidos por chineses e seus produtos criados a partir de uma ideia originalmente concebida nos Estados Unidos, porém de menor qualidade. Os chineses se esforçariam para não deixar transparecer a cópia tornando-a muito similar à original. As escolas de samba do Recife, por sua vez, não conseguiriam copiar de forma absoluta as fantasias do Rio de Janeiro sem o dinheiro, o material e a tecnologia necessários. Assim, é preciso mexer na ideia original com criatividade. Além disso, para eles, é preciso saber esconder as referências para não ficar "malvisto" diante de seus pares, considerado um carnavalesco pouco criativo, um mero imitador "chinês".

Eu também gosto muito do carnaval da Beija-Flor. E, quando você vive no meio, você vai aprendendo. Não é vergonhoso copiar nada, porque hoje o mundo é feito de cópia mesmo. Não é à toa que a cidade está invadida por chineses com cópia de CDs, jogos eletrônicos, bolsas, óculos, celulares "ching ling", de tudo que a gente possa imaginar. Eles pegam a ideia boa, original, dos Estados Unidos e copiam do jeito deles, com os materiais mais baratos. Fica de menor qualidade, claro, mas servem igual e às vezes você nem percebe que é made in China. E eu acho que você me copia, eu copio você, e o mundo é assim mesmo. O meu eu faço, mas não dá pra perceber que é cópia. Por exemplo, aquela roupa eu criei a minha ideia em cima da ideia dos orixás da Beija-Flor. Se eu vir em outra escola, eu reconheço porque eu acompanho muito; até as escolas do Rio copiam uma às outras. São Paulo copia muito o Rio; quando eu vejo São Paulo desfilando, eu digo a todo mundo: essa roupa ele copiou de tal escola (HILÁRIO).

A ideia de inspiração nas escolas de samba do Rio de Janeiro, entretanto, é cautelosamente elaborada pelos grupos pernambucanos. Nas falas das lideranças entrevistadas, aparece a negação da "cópia" absoluta e a valorização da produção independente do desfile carioca, com autonomia para intervenções, reinterpretações e contribuições ao "movimento de samba do Recife":

Tem escola que copia as coisas do Rio, copia tudo, não cria nada, não tem nenhum breack criado por ela. Nada. Essa não contribui para o movimento de samba na cidade do Recife. A gente tem que 
Figura 4: Desfile da Gigante do Samba (Recife), 2013, bateria vestida de oficial da Marinha, inspirada na Beija-Flor (Rio de Janeiro) em 2011 Foto: Hugo Menezes

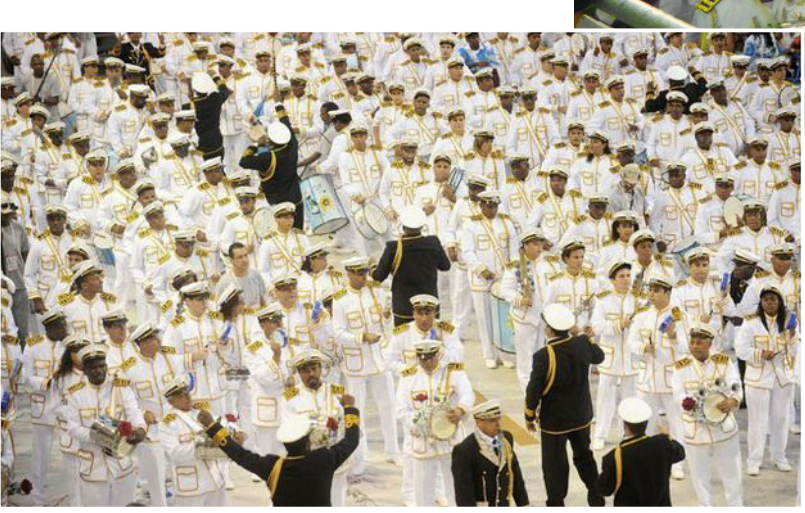

Figura 5: Desfile da Beija-Flor, 2011, bateria vestida de oficial da Marinha Foto: Hugo Menezes

se inspirar, mas também tem que fazer do nosso jeito; precisam ficar independentes, senão seremos só uma sombra de outro, do Rio de Janeiro (SAÚBA, Galeria do Ritmo).

A gente copia as coisas belas. Tem coisa que é cabível, mas tem coisa que é inadmissível copiar, senão a gente vira sempre xerox de fulano, de sicrano. As nossas batidas de baterias têm umas iguais, mas têm outras bem diferentes; o nosso samba tem que ter uma diferença. Elas são ricas em tudo, mas nós somos ricos de criatividade (LACERDA, Gigante do Samba).

Me inspiro em todas. Fico de olho no figurino, mas não faço igual não, coloco a minha criatividade. Ninguém pode dizer que eu copio; eu fico esperta, faço parecido; copiar não, é feio, e a gente não tem dinheiro para isso. Agora eles deveriam vir aqui para ver o que a gente faz com um orçamento de $\mathrm{R} \$ 12.000$; milagre (CONCEIÇÃO, Unidos de São Carlos).

Embora as falas dos representantes pernambucanos evidenciem agenciamentos da noção de criatividade, afastando-se o quanto podem do conteúdo negativo da ideia de "cópia", às vezes a "fonte de inspiração" surge de modo ululante, e a "cópia" é inevitavelmente assumida. O carnavalesco da Gigante do Samba, Hilário, se denuncia: "Eu admito algumas cópias mais fortes, como a bateria desse ano [2013], que eu vou botar toda de marinheiro, idêntica ao oficial da Marinha, inspirado na minha Beija-Flor no ano de Roberto Carlos [2011]". As figuras 4 e 5 confirmam tal informação. 


\section{AS "EMPRESAS DE SAMBA"}

A percepção das lideranças das escolas de samba em Pernambuco sobre o processo de construção do desfile carioca se baseia na noção de profissionalismo. A imagem construída é a de uma "empresa de samba", em que tudo é essencialmente organizado, programado e bem remunerado. O resultado final exibido no desfile viria dessa junção de criatividade, dinheiro e organização.

Parâmetros empresariais foram levantados como norteadores da dinâmica de produção do Rio de Janeiro e colocados em oposição ao "amadorismo" dos grupos de Pernambuco. Dois temas chamam a atenção como constituintes exemplares da imagem da "empresa de samba": o da "frequência obrigatória" dos componentes da escola às atividades e aos ensaios para o carnaval - em comparação às dificuldades de reunir os integrantes nas agremiações do Recife; e o do "planejamento estratégico", com cumprimento fiel do cronograma de atividades - contrastando com a falta de planejamento e infraestrutura dos grupos recifenses.

Ali eu vejo como uma empresa. No dia do ensaio, todo mundo tem que estar, se não estiver é cortado, sem pena. Coisa que aqui não acontece, se eu cortar, não tem outro para botar no lugar, porque lá eles têm fila para ser batuqueiro, sai um entra outro, simples assim. Quer não? Até logo! Lá eles conseguem fazer os ensaios por ala, ala de caixa, ala de repique. Aqui a gente não consegue porque o pessoal trabalha, vem numa semana na outra não vem. Aí a gente tem que passar o trabalho pro grupo, é tudo misturado. Isso no final gera uma diferença no som, no desfile, em tudo. Então lá é como uma empresa, tem que bater o cartão todo ensaio, isso faz diferença (FERNANDO, Unidos de São Carlos).

Eles têm seis meses para ensaiar a bateria quase todo dia; eles se preparam para fazer aquele som maravilhoso, um bom som. E a ordem é: se faltar é cortado. Aqui a gente pede pelo amor de Deus para que as pessoas fiquem, e muitos vão pra avenida tendo ensaiado quase nada, para não dizer nada. Lá o que o mestre de bateria pedir o presidente atende, no dia seguinte; tem demora não, porque eles são uma empresa. Um comunica para o outro, libera o dinheiro e compra. Também porque eles têm o dinheiro sempre em caixa, disponível. Aqui eu digo: presidente, está faltando pele [e ele diz: não tem, não tem dinheiro], está faltando baqueta [ele diz: não tem], está faltando esteira nos caixas... E a gente se vira, tem que arrumar, recicla, pega dos caixas velhos... A gente não trocou nenhuma pele de surdo de 2012 para 2013, ele colocou remendo 
nos que tinham para não furar, e ainda furou um na passarela. Isso tira a qualidade do som (naná, Galeria do Ritmo).

Lá no Rio agora, em outubro, eles já estão prontos, faltando só detalhes, e os segredos que é para ninguém saber. Os caras são profissionais, não é isso aqui que a gente vive não, essa palhaçada. 0 design deles já está pronto, o making off, a palavra não é essa não mas eu vou usar, o making off das fantasias já está pronto. Aqui, se você perguntar qual é a escola que está pronta, só a Gigante está mais ou menos porque ela é a rica daqui. Só deve estar faltando os carros alegóricos (valdo, Limonil).

$\mathrm{Na}$ imagem das "empresas de samba", os profissionais, são assíduos e muito bem remunerados, além de haver um "exército de reserva". As pessoas vivem do samba e recebem salários em cifras inflacionadas, que ganham ainda mais substância quando comparadas aos valores correntes no universo do carnaval do Recife. Imagina-se um mercado cujos altos valores pagos pelos serviços e as negociações entre profissionais e as escolas sejam a tônica dos bastidores do carnaval carioca, em detrimento dos vínculos afetivos com as escolas e as comunidades.

Renato, meu enteado, pesquisa tudo sobre samba; aí essa semana ele disse que o primeiro casal da Portela foi exonerado... Aí ele disse que é exonerado sim, porque eles recebem salário, é $\mathrm{R} \$ 20.000$ por mês! E eles saíram porque queriam mais, e a Escola não deu. Fiquei besta, menino. Eles estavam achando pouco, saíram, vem uma mais rica do que a Portela, uma Beija-Flor e oferece mais. É um mercado. Quem não quer ser porta-bandeira da Portela pra ganhar R\$ 20.000 por mês? Um carnavalesco de uma escola de acesso, a Império da Tijuca, ganha $\mathrm{R} \$ \mathbf{5} .000$ por semana, é $\mathrm{R} \$ 20.000$ por mês! (MARIZE, Gigante do Samba).

Tu pensa que eles respeitam, têm ética? Lá é no quem dá mais, tem esse negócio de amor não. As escolas tiram o carnavalesco, a porta-bandeira, o mestre de bateria da sua concorrente. Oferecem uma proposta melhor e levam. Claro, oferece não sei quantos mil a mais, aí o povo vai, a não ser que role uma contraposta, mas isso fica por trás das cortinas, ninguém sabe (SAÚBA, Galeria do Ritmo). No Rio se torna mais fácil fazer o samba. As coisas saem bonitas porque a verba é maior, tem exigência, mas a verba é maior, a turma sabe como trabalhar, tem muitos carnavalescos bons e eles trabalham satisfeito e de bolso cheio. Olhe um carnavalesco deve ganhar em torno de uns $\mathrm{R} \$$ 200.000. De uma vez não, por mês. Um mestre da bateria não ganha menos de que R\$ 100.000 por mês, 
lá, o daqui eu dou só a passagem $R \$ 5,00$ e o lanche, às vezes uma cerveja. É outro mundo. A menina daqui, da Queridos da Mangueira, estava conversando comigo semana passada que Paulo Barros, da Tijuca, ganhava um milhão por mês... (CARLoS ALBERTo, Unidos da Mangueira).

No imaginário dos sambistas pernambucanos, os carnavalescos são bem remunerados para criar, mas, não participam da execução das atividades, coordenam e fiscalizam o trabalho "da empresa". Para Lacerda, o presidente da Gigante do Samba, os trabalhos de construção das alegorias no Rio de Janeiro, por exemplo, são terceirizados, feitos por uma "empresa licitada", escolhida entre várias concorrentes, que emprega mais de 200 trabalhadores com a finalidade de executar o projeto do carnavalesco, tal qual fora idealizado e no tempo estipulado pela diretoria da agremiação - eficiência nos prazos e na qualidade do produto garantida pelo sistema gerencial das escolas.

As alegorias não têm esse negócio da gente fazer não. As escolas contratam uma empresa que faz. É uma licitação, tem muitas empresas dessas lá no Rio, responsável por fazer alegorias e outras coisas para as escolas. O carnavalesco dá a planta do carro e, em quatro meses, está pronto. São uns 200 trabalhadores, ou mais. Aqui não, aqui é a gente mesmo que faz. Tenho certeza de que o carnavalesco lá nunca pegou em ferro, papel, cola, como a gente aqui. Para fazer alegoria, eu tenho seis, no máximo, 10 pessoas, na dificuldade... Aí é que a gente diz: como é difícil fazer samba numa cidade como essa. Mas é o amor pelo samba (LACERDA, Gigante do Samba).

Para Valmir, responsável pelas alegorias da Limonil, ser carnavalesco é a "melhor profissão do Rio de Janeiro". Eles são ricos, famosos:

Aqui a gente não tem dinheiro não. Um carnavalesco no Rio ganha uma média de $\mathrm{R} \$ 45.000$, o que ganha pouco, porque o que ganha muito, eu não sei nem te dizer valores. Acho que é dinheiro que não acaba mais. Eles são todos ricos, carros importados, mansão e cobertura. Ser carnavalesco é a melhor profissão que tem no Rio, eles são celebridades. E é só para mandar, que eles não botam a mão na massa, não. Eles mandam um povo fazer, e vão lá só olhar. Um pessoal tipo terceirizado, como uma empresa mesmo faz. Eles têm uma filosofia de empresa, chefe é chefe, carnavalesco não bota a mão na massa. $O$ peão faz isso (VALMIR, Limonil).

Nessa imagem de "empresa de samba", as escolas cariocas aparecem como potências na captação de recursos, empreendedoras. Não há dificuldades para levantar capital através de parcerias e patrocínio do setor privado; pelo con- 
trário, os patrocinadores são os maiores interessados em custear os desfiles. A Prefeitura do Rio de Janeiro aparece como uma grande patrocinadora, destinando cifras milionárias de fomento público ${ }^{10}$ às suas agremiações. Considerado o baixo valor da subvenção concedida pela Prefeitura do Recife, a atuação do poder público é imaginada de forma bem diferente da realidade das representantes pernambucanas do gênero.

Lá é muito fácil, é tudo dado. As empresas correm atrás das escolas. Aqui não dá pra ser assim, porque a gente tem que correr atrás. Tem que fazer uma festa, e lá tem muita gente pra apoiar, tem patrocinador sobrando. Lá, quando faz festa, vai uma Skol, Schin e enche o caminhão, o freezer fica cheio, tudo patrocinado, então o lucro do bar é de $100 \%$. Aqui você vai procurar a cerveja que está mais barata e que a turma consegue tomar, para vender e lucrar $\mathrm{R} \$$ 0,50 ou, no máximo, $R \$ 1,00$ por lata vendida. Lá não faz bingo que nem a gente aqui, para vender uma cartela a $\mathrm{R} \$ 1,00$. A prefeitura investe nelas, o governo investe, e dão muito dinheiro. Carnaval aqui em termos de samba, governo, prefeitura, é difícil apoiar. Tem que fazer porque gosta (FERNANDo, Unidos de São Carlos).

O carnaval da Beija-Flor esse ano (2013) é 18 milhões. Só o Jockey Club deu oito milhões. Sabia? E foi o próprio Jockey que foi lá oferecer o enredo e o patrocínio. Ela ainda abre o carnaval da Holanda, ela abre o carnaval do Japão, ela abre o carnaval da Argentina, entra muito dinheiro, por isso que ela faz o povo voar na Sapucaí. Ela tem pra gastar, e a Prefeitura ainda ajuda, dá muito dinheiro. Aqui a gente faz uma tocada (com a bateria) para a Prefeitura no carnaval, quando tem, é $\mathrm{R} \$ 1.000$ para receber não sei quando. Aí é $\mathrm{R} \$ 200$ pro ônibus, $\mathrm{R} \$ 200$ para o mestre de bateria, tem que dar alguma coisa para a bateria, a escola fica com o quê? Muitas vezes as pessoas de fora não sabem as dificuldades de botar uma escola na rua aqui em Recife, mas, lá no Rio, é beleza (NADO, Limonil).

Além dos patrocinadores e da Prefeitura, o jogo do bicho ${ }^{11}$ e o tráfico de drogas $^{12}$ são apontados como importantes fomentadores do carnaval carioca. A contravenção, o contrabando, o investimento de banqueiros de bicho e chefes do tráfico explicariam os orçamentos elevados. No caráter generalizante das impressões pernambucanas, todas as escolas receberiam dinheiro dessas fontes, mantendo com a ilegalidade relação bem resolvida e de conhecimento público. Nas falas dos interlocutores, não há juízo de valor negativo, condenatório; essa forma ilícita de composição de orçamento apareceu naturalizada como parte do processo de produção. Por conseguinte, a participação dos banqueiros de bicho é asso- 
ciada a grandes investimentos, a desfiles luxuosos, ao sucesso do modelo estético e organizacional atual das escolas do Rio de Janeiro. ${ }^{13}$

O material deles todos vem da China, vem de fora. Na Mocidade mesmo, quando Castor era vivo, vinha da China, dos EUA. Vem contrabandeado, não é surpresa para ninguém. Esse TNT (tecido sintético de baixa qualidade) eu comprei do povo do Rio, certamente veio contrabandeado. Eu comprei 900 metros de TNT por $\mathrm{R} \$ \mathbf{7 0 0 , 0 0}$. O metro dele aqui estava $\mathrm{R} \$ 4,50$. Eu ainda tenho aí uns 200 metros. Lá os bicheiros mudaram tudo, eles bancam tudo, mandam buscar tecidos fora, de muito, porque é mais barato. Com os bicheiros era um derramamento de dinheiro. Um carnavalesco, eu não sei quanto eles ganham, mas deve ganhar ótimo, na casa dos milhões, porque bicheiro quer ganhar não quer perder, e ele é bandido, paga para ganhar. Quando todas as escolas tinham os bicheiros foi quando elas mais cresceram e viraram essas empresas. Joãozinho Trinta ganhou muito dinheiro do bicho, tinha amor por aquilo, mas ganhou muito dinheiro também (CORREIA, Samarina).

No Rio, todo mundo sabe, você vai fazer um enredo já chega muito bicheiros querendo entrar na jogada para lavagem de dinheiro. No Rio as escolas andam, porque têm recursos, têm patrocinador oficial e o bicheiro por trás. Lá ninguém trabalha feito aqui não, na unha, na tora, aqui até ferramenta a gente tem que inventar. Lá tem uma forma de trabalhar que foi os bicheiros mesmo que colocaram, é diferente, o dinheiro arruma a casa (VALMIR, escultor da Limonil).

É muito dinheiro, o jogo do bicho deve mandar uns quatro milhões para cada uma, só os bicheiros, como Castor de Andrade, ele já morreu? Não sei, mas se ele morreu a família cuida, porque é genético, fonte segura de dinheiro. $E$ tem a bandidagem também que obriga as pessoas a dar dinheiro pras escolas. As pessoas ajudam com medo das represálias dos chefes do tráfico. Eles dão dinheiro para ficar bem com a comunidade. Aqui a gente não pode nem pensar em fazer isso (JARLAN, Limonil).

As impressões sobre a "empresa de samba" são elaboradas também a partir do contato direto entre os sambistas pernambucanos e as escolas de samba do Rio de Janeiro. Alguns dos interlocutores entrevistados passaram temporadas na capital fluminense, trabalharam nos barracões, conheceram de perto a produção do desfile carioca, trouxeram lembranças, percepções e aprendizados aplicados na construção do desfile de suas agremiações para o carnaval do Recife. Entre os conteúdos mais frequentemente trazidos à baila estão o aprendizado das 
técnicas e do uso de materiais novos, o poder de adaptação a uma realidade muito distinta e as mudanças promovidas por essa vivência.

Fui para o Rio de Janeiro em 1972 e fiquei até 1978, lá não desfilei. Ficava só olhando, ia para a concentração das escolas, para ver como é que era. Lá já era naquela época tudo muito organizado, o pessoal tem muita força de vontade. Quando eu cheguei aqui, mudei muita coisa aqui da bateria de Galeria. Mexi nas afinações e na maneira de repassar as coisas. Faz tempo, mas eu acho que ainda hoje lá é assim. Se antes era organizado, tudo no seu devido lugar, agora são grandes empresas (MESTRE NANÁ, Galeria do Ritmo).

Eu já trabalhei no barracão da Beija-Flor, passei seis anos no Rio. Foi show de bola, a gente aprende muita coisa lá. Hoje eu sou artista plástico, e esse é o primeiro ano aqui. É muito diferente Rio e Recife. Aqui é reciclagem e a gente tem que se adaptar. Lá trabalha com reciclagem, mas é muito pouco, é tudo novo. Lá eu recebia por semana e tinha tudo o que eu queria, tudo o que eu precisava. Aqui eu recebo quando tem dinheiro. Era uma grande empresa. Era muito trabalho, o carnavalesco era muito perfeccionista, mas dava condições. Deve continuar assim, porque a gente só vê as escolas cada vez maiores, mais desenvolvidas (VALMIR, Limonil).

Eu morei no Rio em 1981, minha escola lá era de perto de onde morei, em Bangu, a Mocidade Independente de Padre Miguel. Lá eu aprendi muita coisa nos barracões, a esculpir, fazer trabalho com resina, eu visitava os barracões dos blocos. Fui na Mocidade, Tijuca, na Salgueiro, até Beija-Flor eu fui. Era tudo já profissional, organizado, um lugar de trabalho não de amadores, por isso que está assim hoje. Lá fui também ritmista. Agora aqui eu sou presidente, mas eu sempre fui batuqueiro, aprendi lá a tocar cinco instrumentos diferentes, porque a gente está na vida pra aprender e eu aprendi lá no Rio muito do que eu sei hoje (CORREIA, Samarina).

Não obstante, a percepção sobre a organização empresarial e, consequentemente, sobre a ordem e o sucesso das escolas de samba do Rio de Janeiro talvez não corresponda totalmente à realidade. Sua veracidade, contudo, não é relevante diante do poder dessas representações para a identificação das escolas de samba pernambucanas com um modelo ideal de produção do desfile.

\section{A IMAGEM DA OSTENTAÇÃO: LUXO E RIQUEZA}

Como é o carnaval do Rio? Luxo e riqueza, meu bem! Só glamour, só ostentação, tudo de muito, tudo do bom, sem mendicância. Eles gastam sem dó; é fartura. Nós somos os primos pobres e distantes (MARIZE, Gigante do Samba). 
A “imagem da ostentação" é a mais recorrente. Diz respeito à noção de grandiosidade, "luxo e riqueza", nos termos de Marize, da Gigante do Samba, atribuída às escolas cariocas. Pensei em nomeá-la como "imagem da imponência", porém, a partir da comparação proposta pelos sambistas pernambucanos entre os seus trabalhos e o das coirmãs cariocas, o conceito de ostentação surge com mais vigor diante de uma autoimagem oposta, de extrema simplicidade. A análise do ex-carnavalesco pernambucano Américo Barreto que, durante muitos anos, trabalhou no carnaval do Recife em várias agremiações de samba (entre elas a Samarina), ajudou a qualificar essa impressão coletiva e a definir a ostentação como palavra-chave:

É ostentação mesmo. Esse ano (2013), nós já vimos na passarela do Recife uma fantasia de índia com um cocar com duas penas de passarinho! Quando você vai para o Rio, uma fantasia de índio tem um bando de passarinho da cabeça aos pés, uma revoada inteira na cabeça em um cocar. O que o povo pensa sobre o Rio, aqui em Recife, é a mais pura realidade. Lá é aquela coisa de material por cima de material, tecido, pena, galão tudo pra dar efeito e ostentar também. Então essa comparação é a mais verdadeira possível; é o luxo versus o lixo (AMÉRICO BARRETO).

Américo Barreto também já trabalhou nos barracões das escolas cariocas (na Mangueira e na Unidos da Tijuca), por isso fala sobre o material diferenciado e caro usado no Rio de Janeiro, e destaca a técnica de sobreposição desses materiais para a confecção de fantasias e alegorias, o que dá o sentido da ostentação.

Até hoje tem gente que não sabe o que é um aigrette aqui em Recife, porque nunca chegou no mercado; é uma pena de garça. Outra pena muito usada lá é a pena de pavão; aqui é absurdamente caro, eles ostentam bandos inteiros de pavões e faisões nas fantasias, da cabeça aos pés, principalmente dos destaques e da portabandeira. Aqui, uma pena de pavão mede no máximo $50 \mathrm{~cm}$, lá tem até de $2 \mathrm{~m}$. Um chumaço de penas custa $\mathrm{R} \$ 1$ 1.500. Como os pobres daqui podem comprar? É o luxo que ofusca o lixo. No Rio uma fantasia de um destaque tem muito mais penas do que as de uma ala daqui (AMÉRICO BARRETO).

Reiterando o emblemático exemplo de Américo, há muito mais penas ${ }^{14}$ na fantasia de um só destaque de uma escola do Rio de Janeiro do que em uma ala inteira de uma escola pernambucana. Essa constituinte da "imagem da ostentação" foi acionada em vários momentos por diferentes interlocutores: com um fragmento do carnaval carioca é possível produzir grande parte do desfile do carnaval do Recife. Relatos de diretores contam sobre uma única fantasia de ala ca- 
rioca transformada em um, e até mais de um, destaque no desfile recifense; ou que imponentemente vestiram comissões de frente e foram vistas como luxuosas no desfile recifense; ou roupas de um ritmista do Rio de Janeiro que se transformam no figurino de um mestre-sala em Pernambuco. Comum são as narrativas de uma única fantasia da Sapucaí que se divide e compõe cabeças, adereços de mão e resplendores de criações pernambucanas:

A menina que costura pra gente tem uns parentes no Rio que saem na Mangueira e, depois, ela manda as fantasias pra gente. De uma só de ala que ela mandou a gente fez três destaques. Porque tem muito tudo na peça, muita pena, muito galão, muito paetê, aí a gente vai esfacelando a fantasia e dividindo (CARLOS ALBERTO, Unidos da Mangueira).

Uma roupa de ala lá, se vier toda direitinha pra cá, ela entra como destaque, já fizemos isso, e a que veio de lá era a roupa mais bonita que a gente tinha no desfile. Uma roupa só, de ala mesmo, que venha de lá, a gente faz a festa aqui. Se vier seis roupas de ala, a gente faz 12 para a comissão de frente e fica lindo. Uma bateria de lá é uma escola de samba inteira daqui (ITAMAR, Unidos de São Carlos).

Aqui já teve escola grande que a roupa da bateria da Beija-Flor foi a roupa do mestre-sala. Não tiveram nem o desprazer de mudar uma cabeça, fazer um resplendor, nada. O jurado nem se ligou e deu dez para ele. Aqui é assim (NADO, Limonil).

Os pernambucanos pensam que as escolas de samba do Rio de Janeiro usam pouco o recurso do reaproveitamento e desperdiçam muito material após o desfile, dinâmica entendida como sinal de ostentação. A "imagem da ostentação", então, também se constrói amparada na noção de obsolescência programada. ${ }^{15}$ As fantasias e alegorias do desfile das escolas de samba do Rio de Janeiro seriam "programadas para durar" apenas os 90 minutos do desfile da Marquês de Sapucaí, em seguida, sem uma dinâmica de reaproveitamento, tornam-se obsoletas, transformam-se em lixo.

Nessa lógica, com bases na sobreposição de materiais e na "obsolescência programada carnavalesca", as escolas cariocas ostentam e desperdiçam. Em contrapartida, suas coirmãs do Recife imaginam-se usufruindo desse excedente. Para seus dirigentes, o lixo do carnaval do Rio de Janeiro é uma imagem forte, seria a solução para os problemas, significaria a possibilidade de uso de materiais caros e/ou inexistentes no mercado da cidade, traria beleza ao desfile e uma conexão direta entre os dois estados. 
Dá pra fazer um carnaval aqui com o lixo deles, dá de sobra. Se a gente fosse mais unido, o povo de samba daqui e o povo do samba de lá, isso daria certo. Porque aí eles mandavam o lixo para a gente; lixo é lixo, eles não vão usar, e faria a alegria das escolas daqui (VALMIR, Limonil).

Às vezes eu paro e fico só pensando... Se a Beija-Flor fizesse uma caridade e mandasse o lixo dela pra mim. Eu sempre gostei da Beija-Flor, por causa do passarinho e de Joãozinho Trinta. De 10 anos pra cá, ela é primeiro, segundo ou terceiro lugar, sou fã. Só o lixo dela eu ganharia aqui disparado e fazia carnaval, dois anos seguidos de carnaval. Tentei falar com eles, mas não tivemos resposta (JARLAN, Limonil).

As lideranças entrevistadas falam da vontade de assistir ao desfile no sambódromo da Marquês de Sapucaí; todavia, a dispersão aparece como lugar de desejo, principalmente depois dos desfiles das campeãs: "é quando eles jogam tudo fora, tudo vira lixo" (NANÁ, Galeria do Ritmo).

No Rio eles não reciclam. O lixo, eles dão para os blocos ou fica na avenida, queria eu poder ir pra avenida. No dia do desfile das campeãs, você pode ir pra lá que, na pior das hipóteses, você traz 10.000 plumas. Mas eles não facilitam e a gente não compra material no Rio, porque sai quase o mesmo preço (NADO, Limonil).

Você ficando ali na dispersão, você monta umas três escolas, porque vai terminando os desfiles, e a turma vai deixando tudo no chão. Essas plumas brancas (ele mostra) vêm do Rio de Janeiro, um amigo conseguiu mais barato, é o lixo do ano passado de lá (ITAMAR, Unidos de São Carlos).

Eu tenho vontade de ir pro Rio, mas, para catar o lixo deles, porque o deles é rico, e o da gente é pobre. Eu queria ver os desfiles e, depois, eu queria catar o lixo, meu aperreio é o lixo. (...) Se tivesse uma fusão, uma união tanto das de lá como as daqui... A gente já tentou entrar em contato pela internet, mandar mensagem, mas eles disseram que não podiam ajudar, porque não conheciam escola pelo nome de Unidos de São Carlos. Aí isso já magoou muito a gente, porque tanta coisa que eles jogam no lixo... (CONCEIÇÃo, Unidos de São Carlos).

Há nessa "imagem da ostentação", entretanto, um encantamento que impossibilita discernir o luxo e a "impressão de luxo" (CAVALCANTI, 2006), propositalmente transmitida pelas escolas de samba do Rio de Janeiro, bem como o pouco conhecimento da dinâmica de reaproveitamento do material, pois o "lixo" do Grupo Especial circula e chega àquelas dos demais grupos. ${ }^{16}$ Vale ressaltar que 
as escolas pernambucanas também se ajudam; o excedente (nem sempre o lixo, mas também a sobra da produção) da Limonil, segundo seu presidente, é doado para a Escola do Grupo I, Raio de Luar, e o da Gigante do Samba é doado a sua concorrente do Grupo Especial Unidos de São Carlos.

\section{O ESPELHO INVERTIDO}

Apreender impressões das lideranças das escolas de samba de Pernambuco sobre o universo do desfile carioca, em certa medida, permite visualizar agenciamentos no jogo de alteridade e no processo de construção de sua autoimagem. No entanto, as recorrências sistematizadas são representações, ${ }^{17}$ servem para iluminar problemas, e categorias não se encerram em si. Por esse prisma, é possível identificar, e posteriormente aprofundar, nuanças da dinâmica de produção e da vida social de um conjunto de agremiações do carnaval do Recife que, embora importante, ainda recebe pouca atenção no campo das pesquisas antropológicas. ${ }^{18}$

O olhar de tais lideranças para o outro referencial revela, como efeito inadvertido, o modo pelo qual lidam com as percepções elaboradas, o quanto os mobilizam as diferenças e as similitudes formuladas. Como disse Conceição, da Unidos de São Carlos, em resposta à pergunta inicial, "Como é fazer escola de samba no Recife?", "Tudo é escola de samba, a gente é por um lado tudo igual porque temos na mente as mesmas coisas, seria um espelho. Mas, a gente olha direitinho para elas e parece que o espelho está de cabeça para baixo".

\section{NOTAS}

1 Nos termos de Hall (2003, p. 134) "Em última análise, trata-se de onde e como as pessoas experimentam suas condições de vida, como as definem e a elas respondem".

2 Aproximo as narrativas dos sambistas pernambucanos acerca das escolas de samba do Rio de Janeiro ao que Becker (2009, p. 151-152) entende por "representações irrealistas": "descrições idealizadas removendo detalhes que não precisam ter a forma que assumem em algum caso histórico; e, ao fazê-lo revela os mecanismos organizacionais idealizados ['perfeitos'] que um exemplo empírico esconde. Representações como essas nos mostram como as coisas seriam se funcionassem daquele modo, se as forças em jogo, não estorvadas por detalhes irrelevantes e estranhos, pudessem revelar sua natureza essencial".

3 Em consonância com Perez (2011, p. 101): “Como forma lúdica de sociação e como operador de ligações a festa, simultaneamente e a uma só vez, expressa 
sentimentos, emoções e sonhos coletivos, estrutura pautas e códigos de vínculo, gera imagens multiforme da vida coletiva".

4 Nos termos de Souza (2011, p.30-31): "conjunto de interpretações e de ideias que permitem compreender o sentido e a especificidade de determinada experiência histórica coletiva".

5 A tese intitulada Tem samba na terra do frevo: as escolas de samba no carnaval do Recife, orientada pela Profa. Dra. Maria Laura V. de C. Cavalcanti, foi defendida em 2014 no Programa de Pós-graduação em Sociologia e Antropologia da Universidade Federal do Rio de Janeiro (PPGSA/IFCS/UFRJ).

6 A pesquisa para a tese foi realizada com as seguintes escolas pernambucanas: Unidos de São Carlos, Limonil, Samarina, Unidos da Mangueira, Galeria do Ritmo, e Gigante do Samba. Os dados foram produzidos por meio de entrevistas semiestruturadas com lideranças e componentes dessas escolas; na última realizei observação direta do processo ritual do desfile.

7 A diretoria da Gigante do Samba, frequentemente endossa seu currículo de serviços prestados ao samba em Pernambuco destacando a parceria com nomes de artistas do mundo do samba do Rio de Janeiro. Com orgulho, Lacerda, o presidente da escola, levanta as personalidades do samba carioca que já tocaram na quadra da Gigante: “Aqui em Gigante já veio Alcione, Jamelão, Leci Brandão, Zeca Pagodinho, Jorge Aragão, Martinho da Vila. E Neguinho mais de uma vez. A bateria daqui toca o repertório dele e ele rapidamente se afina com o pessoal quando vem pra cá."

8 Um repertório "para dar sentido ao mundo sem [as escolas] serem rigorosamente atadas a ele em cada detalhe de sua existência" (HALL, 2003, p. 70).

9 No qual concorrem as escolas, distribuídas em Grupo Especial, I e II. Ver Menezes Neto (2014).

10 Cavalcanti (2009, p. 108) informa que o desfile de uma escola de samba não custaria menos do que cinco milhões de reais. Essa pequena fortuna viria do repasse de parte da arrecadação da Liesa do ano anterior (venda de ingressos, patrocínios) distribuídos de acordo com o ranking do último concurso, do fomento público da Prefeitura (mais de dois milhões), mais outros patrocínios e receitas produzidas na quadra. Escolas como Beija-Flor e Mangueira chegam a orçar oito milhões de reais. Barbieri (2009, p. 142) também comenta a realidade díspar entre as escolas do Grupo Especial e os demais grupos do carnaval carioca, que se reflete diretamente na distribuição desigual da subvenção pública para os diferentes grupos. Barbieri fala em cifras milionárias para o Grupo Especial (orçamentos estimados em quatro milhões de reais).

11 Sobre a relação entre o jogo do bicho e as escolas de samba, ver a acurada análise de Cavalcanti (2009, p. 94): "o principal desfile das escolas de samba da cidade do Rio de Janeiro é hoje administrado não pelo poder público, nem 
exatamente pelas escolas de samba, mas pela organização que representando as grandes escolas de samba, congrega, desde 1984, a cúpula da rede do jogo do bicho na cidade. Com ela os bicheiros ganharam grande visibilidade e prestígio". Sobre o jogo do bicho e o carnaval do Rio de Janeiro, ver também Cavalcanti (1999, 2006) e Queiroz (1992).

12 Cavalcanti (2009, p. 114) alerta que muitas escolas "Veem-se às voltas, com a presença de difícil controle e mais do que poluidora, destruidora, do tráfico de drogas dentro da escola".

13 Para Cavalcanati (2006, p. 52-53), “Um banqueiro de bicho gastava no desfile quantias extraordinárias de dinheiro cujo retorno se dava em outra moeda: o prestígio adquirido com a vitória de sua escola no carnaval."

14 Nas entrevistas ficou claro que usar penas no carnaval é uma referência para os padrões de luxo, e sua ausência é ligada à pobreza, por ser um material muito caro. "Pena é para rico, um quilo de pena é $\mathrm{R} \$ 1.800$. Com que dinheiro eu compro isso?", indaga Conceição, da Unidos de São Carlos. A Gigante do Samba compra penas e outros materiais nos barracões do Rio de Janeiro, por isso vista como "rica" por suas coirmãs: "Só a Gigante, e antigamente a Galeria, que têm dinheiro para comprar pena da melhorzinha, o resto usa pena de fazer peteca mesmo, ela é a rica", complementa a Presidente da Unidos de São Carlos.

15 No campo dos estudos de consumo e de meio ambiente, a obsolescência programada é o nome dado à vida curta de um bem ou produto, projetado para funcionar apenas por um período reduzido, produzindo assim mais consumo. Ver Gonçalves (2011, p. 33).

16 É comum o movimento de doação e circulação de "lixo" para as escolas dos outros grupos do carnaval do Rio Janeiro: "A cada ano muita coisa virava sucata, e era mandada embora, ou passava para outras escolas que repassavam o "lixo" das grandes para as escolas menores e para os blocos" (CAVALCANTI, 2006, p. 156). Sobre reaproveitamento de material e doação para grupos menos abastados, no universo das escolas de samba do Rio de Janeiro, ver também Barbieri (2009). Acompanhei esse movimento na visita realizada ao barracão das escolas de samba dos grupos C, D e E, com Maria Laura Cavalcanti, em setembro de 2010.

17 “(...) imagens que servem para teoria ou explicações de algo, histórias sobre como eventos e pessoas de certo tipo chegam a ser como são" (BECKER, 2007, p.57).

18 Sobre os estudos acerca das escolas de samba do carnaval do Recife, vale ressaltar os esforços atuais do campo da história. Ver Silva (2011) e Lima (2012). 


\section{REFERÊNCIAS BIBLIOGRÁFICAS}

BARBIERI, Ricardo José de Oliveira. Cidade do samba: do barracão de escola às fábricas de carnaval. In: CAVALCANTI, Maria Laura V. C; GONÇALVES, Renata (Org.). Carnaval em múltiplos planos. Rio de Janeiro: Ed. Aeroplano, 2009.

BECKER. Howard S. Falando em sociedade. Rio de Janeiro: Zahar, 2009.

CAVALCANTI, Maria Laura V. C. O rito e o tempo. Ensaios sobre o Carnaval. Rio de Janeiro: Ed. Civilização Brasileira, 1999.

. Carnaval carioca: dos bastidores ao desfile. Rio de Janeiro: UFRJ, 2006.

. Festa e contravenção: os bicheiros no carnaval do Rio de Janeiro. In: CAVALCANTI, Maria Laura V. C.; GONÇALVES, Renata (Org.). Carnaval em múltiplus planos. Rio de Janeiro: Ed. Aeroplano, 2009.

GONÇALVES, Pólita. A cultura do supérfluo. Lixo e desperdício na sociedade de consumo. Rio de Janeiro: Ed. Garamond, 2011.

HALL, Stuart. Da diáspora: identidade e mediações culturais. Belo Horizonte: Ed.UFMG, 2003.

LIMA, Ivaldo Marciano de França. Quem foi que falou em frevo? Em Pernambuco se samba, e muito! Revista Ágora, Vitória, n.16, p. 63-76, 2012.

MENEZES NETO, Hugo. Tem samba na terra do frevo. As escolas de samba no carnaval do Recife. Tese (doutorado em antropologia) - Universidade Federal do Rio de Janeiro, Rio de Janeiro, 2014.

PEREZ, Léa Freitas. Festa, religião e cidade. Corpo e alma do Brasil. Porto Alegre: Ed: Medianiz, 2011.

QUEIROZ, Maria Isaura Pereira. Carnaval brasileiro - o vivido e o mito. São Paulo: Ed. Brasiliense, 1992.

SILVA, Augusto Neves da. Quem gosta de samba, bom pernambucano não é? (1955-1972). Dissertação (mestrado em história) - Universidade Federal de Pernambuco, Recife, 2011.

SOUZA, Jessé. A ralé brasileira: quem é e como vive. Belo Horizonte: Ed. UFMG, 2009.

Hugo Menezes Neto é professor adjunto da Universidade Federal do Pará (UFPA), doutor em antropologia pela Universidade Federal do Rio de Janeiro (PPGSA/UFRJ/IFCS).

Recebido em: 15/09/2014

Aceito em: 26/10/2014 